\title{
Why Nigeria is Not A Member of G-20 Countries
}

\author{
Dr. Chioma D. Oleka ${ }^{1}$ Sir Paschal I. P. Okolie ${ }^{2}$ \\ Department of Banking and Finance, Faculty of Management Sciences, Enugu State University of Science and \\ Technology, Enugu, Nigeria.
}

\begin{abstract}
This paper examines the historical background of the establishment of the group of twenty also known as G-20 countries, criteria for membership, reasons why most emerging/developing countries especially Nigeria could not make the list of G-20. The prospects of Nigeria meeting the unclear requirements of membership of the group in future were also looked into. The paper concluded that some of the developing countries especially Nigeria has the potential to qualify for membership of G-20 and as such recommended that Nigerian leaders should take proactive steps to give the kind of leadership that can encourage industrialization and economic expansion, reduce corruption, create employment, attract foreign direct investment, etcetera. With the above qualities, this paper reinforces the expectation that the G-20 countries will be willing to open her doors to more emerging countries such as Nigeria, the giant of Africa, to join the group considering the progress already made by such countries over the years.
\end{abstract}

\section{Introduction}

Economic size and the financial sector of a nation are usually some of the parameters for determining the chances and possibilities of a country belonging to the G-20. G-20 by the way means Group of Twenty. By 2014 , Nigeria was the $20^{\text {th }}$ largest global economy by parity of purchasing strength and the $23^{\text {rd }}$ largest economy nominally. Equally, Nigeria is the largest economy in Africa and one of the largest in the developing world. She is only surpassed by China, India, Brazil, Mexico, Turkey and Indonesia and these countries are members of G-20 (www.skyscrepercity.com>showthread). In spite of all the above, it is still a puzzle that Nigeria is not yet a member of G-20 when less endowed nations lord it over Nigeria as members of G-20. This shows that there is something wrong somewhere. Our concern in this piece is to examine the possible reasons for Nigeria's inability to make the list of G-20 despite her size, natural endowment and her contribution to the world economy.

\section{Historical Background of Membership of G.20}

The history of the formation and development of G-20 (group of twenty) dates back to 1975 when six nations, namely, Germany, United Kingdom, United States of America, Italy, France and Japan came together to discuss economic issues bothering on the interest of member countries. However, Canada joined in 1976 and the G-7 was formed. It can therefore be said that G-7 was conceived in 1975 and born in 1976. These G-7 countries are super powers and as such they have strong economy and strong currency. It is therefore not surprising that major discussions at their summits centre on economic issues concerning them bearing in mind that they have similar economic situations.

In 1990, G-8 was born with the admission of Russia. Their aim was to facilitate economic cooperation among the world's largest industrial nations. After the formation of G-8, emerging countries complained and agitated because of the inability of G-8 countries to discuss issues affecting developing nations. The emerging nations felt neglected in the scheme of the discussion of world affairs. Consequently, G-20 was formed in 1999 with the admission of twelve (12) additional countries including emerging ones, namely: Argentina, Australia, Brazil, China, India, Indonesia, Mexico, Saudi Arabia, South Africa, Korea, Turkey and European Union. Unlike the time of G-7, discussions extended to issues such as global economic governance, international security and energy policies. In fact the major aim of the emergence of G-20 is to bring together industrialized and developing economies to discuss key issues in the global economy (Telegraph, 2014). He went further to assert that the difference between G-7(8) and G-20 is that "G-7 seeks agreement on current economic issues based on the interest of those countries, while the G-20 reflects the wider interests of both industrial and emerging market economies".

The G-20 summit is rotational among member nations and it is held annually. Under normal circumstances, each summit is attended by G-20 Finance Ministers and Central Bank Governors with the President of hosting nation as chairman. It has no permanent secretariat. The annual summit holds in addition to working group and expert group activities that support the work of leaders of the G-20. For instance, the working groups include: 
- Framework for strong, sustainable and Balanced Growth.

- Anti-Corruption (established at the G-20 Toronto Summit)

- Development (established at the G-20 summit)

- International Monetary Fund Quota and Governance Reform.

On the other hand, the expert groups are:

- Financial Safety Nets

- Financial Inclusion

- Energy

(www.international.gc.ca>... $>$ G.20

\section{Criteria For Membership}

There are no defined or formal criteria for membership of G-20. The composition and membership of the group has remained the same since its inception to date. However, based on the objectives of the G-20, it was considered important that countries and regions with similar economic significance for international financial system should be included (Akshay, 2015). According to Ozgur, (2015) "there are no formal criteria for G-20 membership but all of the members play important roles in their region and the world and they influence and manage world's economy and finance system". Begtin, (2015) goes further to insist that G-20 is a political club and therefore not just 20 major economies, but aims at dialogue among most developed and developing countries. It was therefore formed with economies that are critical to the world markets in mind [Balaji, (2015)]. From the foregoing, it can be seen that the determination of membership is a combination of political, economic and industrial strength of aspiring nations. Problems militating against Nigeria's membership, when and how she will meet the above unclear criteria will be discussed in the next sections of this paper.

\section{Why is Nigeria Not A Member?}

It is worrisome that Nigeria, being presently the largest economy in Africa, is not a member of G-20 which represents $80 \%$ of the world economy. The reason for her inability to make the list is attributable to the stunted growth and development in Nigeria's infrastructure which failure is blamed on the poor leadership by the political class [Okonjo-Iweala, (2010)]. Nigeria is a blessed nation with abundant human/material/natural resources and unbeatable favourable climate. She is the most populated nation in Africa and the largest black nation in the world. She has the potential for massive industrialization and economic expansion which are the major consideration for membership of the G-20. In view of all the above, Peter Draper, Senior Research Fellow, South African Institute of International Affairs observed that the Post Asian Crisis Larry Summers Paul Martin almost included Nigeria in G-20 but could not due to Institutional weakness and endemic corruption. Consequently, Nigeria remains a weeping child going cap in hand for bailout from other world economies. In summary therefore, it can safely be said that Nigeria's inability to make the list of G-20 was caused by, but not limited to:

- Negative attitude to industrialization

- Inept and poor leadership

- Institutional weakness

- Corruption

- Insecurity

- Lack of focus

- Poor international diplomacy

- Infrastructure deficit.

\section{Future Prospect of Nigeria's Membership}

Undoubtedly, Nigeria has the potential to be admitted as a member of this group. However, these potentials need to be harnessed and exploited. It needs a dedicated and committed leader to make this possible. This is because, it is only a committed, focused and detribalized Nigeria leader that can provide the needed leadership that can:

- Aggressively pursue the complete industrialization of Nigeria for creation of employment and economic expansion,

- Create strong institutions

- Fight corruption to a stand still

- $\quad$ Provide security of life and property to attract Foreign Direct Investment (FDI)

- Ensure professional handling of international diplomacy

- $\quad$ Provide needed infrastructure like good roads, power, workable health system, education, etc. 
- Attract Foreign Direct Investment by providing favourable investment climate.

In addition to the above, Nigeria can rightly lay claim to her size as the largest economy in Africa and as such has the potential to represent Africa in the global stage.

\section{Conclusion}

Finally, it can be seen from the above stated facts that Nigeria has the potential to be a member of G-20 considering that less endowed nations are members. What is needed is for the Nigerian leaders to squarely tackle the identified problems that have bugged her over the years and move forward for her possible inclusion in the group, provided that the present G-20 is prepared and willing to open her doors for more admissions in view of recent progress that has been recorded by new emerging countries of the world.

\section{References/Webliography}

[1]. Akshay M. (2015), "What is the criteria for being a member nation of the G-20". Retrieved from https://www.quora.com/whatare-the-criteria-for- being-a-member-nation-of-the-G-20

[2]. Balaji V. (2015), "What is the criteria for being a member nation of the G-20". Retrieved from https://www.quora.com/what-arethe-criteria-for-being-a-member-nation-of-the-G-20

[3]. Begtin I. (2015), "What is the criteria for being a member nation of the G-20." Retrieved from https://www.quora.com/what-arethe-criteria-for-being-a-member-nation-of-the-G-20

[4]. Chiakwelu E. "G-20 Summit: Where is Nigeria the Giant of Africa?"Retrieved from www.gamji.com/article 8000/NEWS 8579.htm.

[5]. History and membership of G-20, Retrieved from www.international.gc.co>...>G.20 on 7/7/16

[6]. Naijabon (2014), "When will Nigeria officially become a G-20 member", Retrieved from www.skycrapercity.com>showthread on $7 / 7 / 16$

[7]. Okonjo-Iweala N. (2014), "Why Nigeria is not in G-20". Retrieved from www.nigeria.70.com/nigeria.newspaper/why-Nigeria-isnot-in-g.20 .../295023 on $6 / 7 / 16$

[8]. Ozgur A. (2015), "What is the criteria for being a member nation of the G-20". Retrieved from https://www.quora.com/what-arethe-criteria-for-being-a-member-nation-of-the-G-20

[9]. Draper P. "Nigeria and South Africa in the G-20". Retrieved fromhttps://www.odi/sites.org.uk/files/odi-assets/eventspresentation/1692 pdf. on $6 / 7 / 16$

[10]. Suan H. R. (2014), "Explainer: who gets invited to the G-20 summit and why". Retrieved from theconversation.com/explainer-whoget-invited-to-the-g 20-and-why33308 on 6/7/16

[11]. Telegraph S. (2014), "G-20: What is it and how does it work?" Retrieved from www.telegraph.co.uk>finance>G.20 on 6/7/16 